\title{
EHMTI-0054. Monthly variation of Tashkent pediatric headache emergency department visits
}

\author{
S Gazieva*, Anna Prokhorova \\ From 4th European Headache and Migraine Trust International Congress: EHMTIC 2014 \\ Copenhagen, Denmark. 18-21 September 2014
}

Headache is the most frequent neurological symptom and the most common manifestation of pain in childhood.

The objective of this article is to determine the monthly variation of emergency department (ED) visits for pediatric headache.

We hypothesized youth have increased headache-related ED visits in the months associated with school attendance.

\section{Methods}

Using a Tashkent representative sample of ED visits in the National Hospital Ambulatory Medical Care Survey from September 2009 to April 2014, we estimated number of visits associated with ICD-9 codes related to headache, migraine, status migrainosus, or tension-type headache in 5- to 18-year-olds. Age-stratified multivariate models are presented for month of visit .

\section{Results}

There was a national estimate 3300 ED visits annually related to headache ( $2.1 \%$ of total visits) in 5 - to 18 -yearolds. In 5- to 11-year-olds, the adjusted rate of headacherelated visits was lower in March (OR 0.42, 95\% CI 0.20, $0.88)$. In 12- to 18-year-olds, there were higher rates in January (OR 1.92, 95\% CI 1.16, 3.14) and September (OR $1.64,95 \%$ CI 1.06, 2.55).

\section{Conclusions}

In adolescents we found higher ED utilization in January and September, the same months associated with school return from vacation for a majority of children nationally. No significant reduction in the summer suggests that school itself is not the issue, but rather changes in daily lifestyle and transitions.

No conflict of interest.

Neurology, Tashkent Medical Academy, Tashkent, Uzbekistan
Published: 18 September 2014

doi:10.1186/1129-2377-15-S1-B9

Cite this article as: Gazieva and Prokhorova: EHMTI-0054. Monthly

variation of Tashkent pediatric headache emergency department visits. The Journal of Headache and Pain 2014 15(Suppl 1):B9.
Submit your manuscript to a SpringerOpen ${ }^{\odot}$ journal and benefit from:

- Convenient online submission

- Rigorous peer review

- Immediate publication on acceptance

- Open access: articles freely available online

- High visibility within the field

- Retaining the copyright to your article

Submit your next manuscript at $>$ springeropen.com

\section{SpringerOpen ${ }^{\circ}$}

(c) 2014 Gazieva and Prokhorova; licensee Springer. This is an Open Access article distributed under the terms of the Creative Commons Attribution License (http://creativecommons.org/licenses/by/2.0), which permits unrestricted use, distribution, and reproduction in any medium, provided the original work is properly cited. 